\title{
EFFECT OF COMPLETE FEED CONTAINING VARIETIES OF STONE BANANA STEM ON KACANG GOAT PRODUCTIVITY
}

\author{
Aswandi \\ Agricultural Extension Collage Manokwari, Jl. SPMA Reremi Manokwari. West Papua Province, Indonesia
}

\begin{abstract}
The objective of this research was to observe the effect of complete feed containing banana stem on kacang goat productivity. Twelve male kacang goats were used with average initial body weight $14.42 \pm 1.98 \mathrm{~kg}$ and ages between 10-15 months. Complete feed made in the form of pellets with a diameter of $7 \mathrm{~mm}$ and length $3 \mathrm{~cm}$. Construction of enclosure measuring $12 \mathrm{~m} \times 6 \mathrm{~m}$ and the construction of the stage as high as $140 \mathrm{~cm}$-story and plot pens measuring $1 \times 1 \mathrm{~m}$ with a height of $130 \mathrm{~cm}$. Rumen fluid $\mathrm{p}^{\mathrm{H}}$, blood glucose, acetic acid, ammonia $\left(\mathrm{NH}_{3}\right)$, volatile fatty acid (VFA), body weight, complete feed intake, dry matter intake, digestibility of dry matter, energy consumption, energy digestibility, feed conversion complete, carcasses and carcass parts are measured. Data were analyzed by t-test. Results showed that the rumen fluid $\mathrm{pH}, \mathrm{NH}_{3}, \mathrm{CF}_{3}$ between treatments were not significantly different $\mathrm{CF}_{0}(\mathrm{P}<0.05)$, whereas propionic acid, butyrate, blood glucose and total VFA differ high significantly $(\mathrm{P}<0.01) . \mathrm{CF}_{3}$ treatment produces propionic acid, Butyrate, blood glucose and total VFA better than the control. Complete feed containing wheat banana stem stone kacang goat productivity is better than complete feed control.
\end{abstract}

Keywords: banana stem stone, complete feed, kacang goat

\section{INTRODUCTION}

Availability of feed non-ruminant and ruminant animals is a problem in developing countries such as in Indonesia. For non-ruminant livestock, many feed ingredients are imported while for ruminants which depend entirely on local materials and often it is difficult to get a feed ingredient as the availability is always not continuous. Searching feed material in the form of by-product agro-industry continues. Cultivation of banana is one of the agro industry business as this plant is the easiest plant to grow and thrive well in Indonesia. Banana weevil is the banana plant stem under the soil surface (bulbs). The chemical composition of banana weevil consists of dry matter (DM) $6.20-13.87 \%$, protein $2.99-3.4 \%$, fiber fat $0.96-7.0 \%$, crude fiber $9.99-16.1 \%$ (Gerona et al., 1987). Banana weevil flour containing 66.2\% carbohydrates and 5.88\% protein. Based on the potential nutritional raw materials, the banana weevil can be used as a material source of energy for ruminant livestock as the feed material contains 20\% less crude protein, crude fiber less than 18\% (Hartadi et al., 1997). Complete feed using local raw materials / agricultural waste in the form of banana weevil has advantages such as readily available materials andcheaper price, lower production costs, easier to distribute and nutrient can be determined in accordance with the needs of livestock. Complete feeds have a competitive advantage compared to commercial feed manufactured large industrial scale because it is more efficient in production and transportation cost, easy storage and can reduce operating cost, especially labor (Sunarso et al., 2007). Kacang goat has the advantage that the production is pretty good, easy to adapt to unfavorable environment, proliferate rapidly and is well known in Indonesian society in general. The objective of this research was to observe the effect of complete feed containing banana stem on kacang goat productivity.

\section{MATERIALS AND METHODS}

Complete feed the best of the second phase of the research starchy banana weevil stone made in the form of pellets with a diameter of $7 \mathrm{~mm}$, with a length of $2 \mathrm{~cm}$. Goats beans used in this study were taken from the area around the study site.

*Corresponding e-mail address: as.wandi73@yahoo.co.id 


\section{Research variable}

Research variables include: Added daily body weight with method of Williamson and Payne (1993). Consumption of complete feed consumption of dry matter, dry matter digestibility, energy consumption, energy digestibility, complete feed conversion, rumen fluid $\mathrm{pH}$, blood glucose, ammonia (NH3), volatile fatty acid (VFA) partial and total method of Goering and Van Soest (1970), carcass and parts of the carcass measured by the method of Forrest et al. (1975).

\section{Experimental design}

The experiment was conducted using a completely randomized design with treatments in the form of two types of complete feed, consisting of CF0 (control) with CF3 starchy tuber varieties of bananas Stone. Each treatment in the study was repeated six times, so overall there were 12 experimental units.

\section{Data collection technique}

For volatile fatty acids, $1 \mathrm{ml}$ rumen fluid as collected and poured into a centrifuge tube and added $0.03 \mathrm{~g}$ sulfosalisilate and then centrifuged for 10 minutes at a speed of 10,000 rpm. From the resulting solution, 0.40 $\mathrm{ml}$ was taken into chromatogram. The VFA and the concentration of NH3 in rumen fluid was measured following the method of Goering and Van Soest (1970).

The concentration of rumen fluid $\mathrm{pH}$, measured by inserting the tip into the liquid rumen $\mathrm{pH}$ meter results from the shelter for 5 seconds, then read on the monitor digitally generated numbers.

Body weight gain, goats weighing is done the experiment beans once a week, at $8 \mathrm{am}$, before the new feeding, using a digital hanging scale capacity of $50 \mathrm{~kg}$ with a precision of $20 \mathrm{~g}$. Body weight is the total weight encroachment during the collection of data is reduced with initial body weight of goat experiment. Body weight gain was measured by the method of Williamson and Payne (1993).

Feed residues are removed from the feed once a day immediately before new feed is given at 08:00. Water were given ad libitum. During the period a total collection of faeces collected using gauze are mounted below the floor of the cage stage. Feces were collected until the end of the study. Furthermore, the wind dried placed in a room, then each treatment samples were collected for analysis of proximate.

Complete feed consumption was calculated from the total feed given during the study reduced the total residual feed during the study. Consumption of feed dry matter is determined by multiplying the total consumption of feed dry matter content

Dry matter digestibility of feed calculated total dry matter intake reduced total dry matter in the feces divided dry matter intake, multiplied by $100 \%$. The energy consumption of feed is determined by the total dry matter of feed consumed multiplied by energy content in the feed. Digestibility of energy in total energy consumption divided minus energy in feces multiply the energy consumption of $100 \%$

Complete feed conversion was calculated from the dry matter intake compared with weight gain. Blood glucose was measured by using the tool (Accu chek) digital, by as much as $1 \mathrm{cc}$ of blood is drawn from the jugular vein by using a sterile disposable syringe, then dropped 1 drop on the Sleat which has been installed, the blood glucose levels can be read directly on the monitor.

Body weight gain, calculated with reference methods Williamson and Payne (1993), final body weight minus the initial weight. Daily weight gain, body weight gain during the study divided by the length of time of the study. Carcass weight and parts of Caracas, do the slaughtering experiment at the end of the study.

Carcass weight and the weight of the parts of carcass, measured denagan method (Forrest et al., 1975)., Neck: start of the vertebrae of the cervical to-1 to vertebrae cervical-7, Shoulder: start of the vertebrae of the cervical 7th until mid costae 5th and 6th, Breast: from sternum straight back up to the projection of the 6th lumbar vertebrae, leg chump on vertebrae from 9th to joint patella.

\section{Data analysis}

Data obtained from all study variables were analyzed using the third phase of t-test, with the application of the MS program, excel guided by instructions of Santosa and Ashari (2005). The composition of feed complete feed dry matter content was calculated based on various compositions of raw materials. The data collected were analyzed by t-test, to know the difference between treatments. 
Effect of complete feed of stone banana stem

\section{RESULTS AND DISCUSSION}

It is indicated that the view of $\mathrm{CF}_{0}$ and $\mathrm{CF}_{3}$ treatment were not significantly different $(P>0.05)$ with the difference between the $\mathrm{CF}_{3}$ with $\mathrm{CF}_{0}$ of $5.75 \%, \mathrm{pH}$ values lower rumen fluid produced $\mathrm{CF}_{3}$, indicating that the acid content (especially VFA) results Fermentative digestion in the rumen was higher.

The findings of the study variables rumen fluid $\mathrm{pH}$ in vivo treatment of $\mathrm{CF}_{3}$ and $\mathrm{CF}_{0}$ are still in the optimum range, so it can be expected that the growth of rumen microbes can still run well. Based on rumen fluid $\mathrm{pH}$ variable, it can be stated that although the $\mathrm{pH}$ of the rumen fluid at lower $\mathrm{CF}_{3}$ of $\mathrm{CF}_{0}$, but if low $\mathrm{pH}$ is associated with the production of volatile fatty acids (VFA) and total, the $\mathrm{CF}_{3}$ is still better than the $\mathrm{CF}_{0}$

Difference in rumen fluid $\mathrm{pH}$ values in both treatments complete feed is related to differences in the chemical composition of complete feed is tested. $\mathrm{CF}_{3}$ complete feed composed of rock flour banana weevil-rich nonstructural carbohydrates, whereas $\mathrm{CF}_{0}$ contain more fiber, forage composition of $70 \%$ king grass, with the chemical composition of the feed crude fiber $67.23 \%, 28.71 \% \mathrm{NDF}$ and $\mathrm{ADF} 38$, of $87 \%$. $\mathrm{CF}_{3}$ contained only $30 \%$ forage, containing $23.71 \%$ crude fiber, with the NDF content of $52.67 \%$ and $48.72 \%$ ADF.

Feed that contain high non-structural carbohydrates in the rumen to stimulate the growth of lactobacilli bacteria and rumen fluid $\mathrm{pH}$ will lead to lower down, as presented by McCormick et al. (2001) who stated that ruminants fed a lot of structural carbohydrates (fiber) will result in rumen fluid $\mathrm{pH}$ tends to move towards 7.5 , whereas if fed with soluble carbohydrate rumen fluid $\mathrm{pH}$ will bring will move toward 5.0. Thus it can be ascertained that the difference in $\mathrm{pH}$ values between $\mathrm{CF}_{0}$ and $\mathrm{CF}_{3}$ is closely related to differences in composition chemical or digestible carbohydrate content between the feed is tested in goat.

T-test results showed that the treatment did not differ $\mathrm{CF}_{3} \mathrm{vs} \mathrm{CF}_{0}(\mathrm{P}<0.05)$ on rumen fluid NH3, with a difference of $1.4 \%$, the average concentration of $3.86 \mathrm{mM} \mathrm{NH}_{3} . \mathrm{CF}_{3}$ while $\mathrm{CF}_{0} 3.75 \mathrm{mM}, \mathrm{NH}_{3}$ treatment $\mathrm{CF}_{3}$ higher than CFO. It confirmed the results of previous researchers (Sutardi, 1977; Muktarudin and Liman, 2006; Chikagwa et al., 2009).

$\mathrm{NH}_{3}$ on the research findings is lower compared with previous research, if confirmed by experiments complete protein content of feed protein content was low at an average of $10.46 \%$, as $\mathrm{F}$ the $\mathrm{NH}_{3}$ concentration reflects the amount of protein contained in feed and rumen mikoroba ability to degrade the feed protein. $\mathrm{NH}_{3}$ levels either complete the digestion of feed and $\mathrm{CF}_{3}$ between $\mathrm{CF}_{0}$ is tested is lower, but $\mathrm{NH}_{3}$ is still in the optimum range for rumen microbial growth.

Test results shows that the treatment did not differ $\mathrm{CF}_{3} \mathrm{vs}_{\mathrm{CF}}(\mathrm{P}>0.05)$ on the composition of acetic acid, with a difference of $3.31 \%$ ie 55.84 to $52.26 \mathrm{mM}$. The findings of acetic acid can be concluded that the complete feed containing rock flour banana weevil, which is rich in easily digestible carbohydrates can indeed reduce the composition of acetic acid.

Differences in the concentration of acetic acid in rumen fluid between the treatment of complete feed $\mathrm{CF}_{0}$. $\mathrm{CF}_{3}$ view found in this study could occur due to possible differences in soluble carbohydrate content between the two complete feed is tested. Soluble carbohydrate in the diet can cause a decrease in acetic acid composition, according to the declared France et al. (1993) that feed the dominant soluble carbohydrates (high fiber), will lead to the production of acetic acid increased, whereas concentrations of soluble carbohydrate (glucose, fructose, sucrose, and polysaccharides (starch) will result in increased concentrations of propionate and butyrate, while acetate decreased Owens et al. (2008) also states that the feed containing straw (structural carbohydrates) produce acetate production increased, while those containing larger concentrations will result in increased production of propionic acid, while acetic acid decreased.

The t-test results showed that the treatment is different $\mathrm{CF}_{3}$ very real view of $\mathrm{CF}_{0}(\mathrm{P}<0.01)$ of propionic acid composition, with a difference of $23.76 \%$, the average composition of propionic acid $\mathrm{CF}_{0}, \mathrm{CF}_{3}: 17.76 \mathrm{mM}$ respectively, 28, $83 \mathrm{mM}$, complete feed containing CF3 Stone banana weevil flour rich in compounds that are easily digested carbohydrates, thus producing propionic acid is higher than the $\mathrm{CF}_{0}$, as reported by previous researchers (Castellejos et al., 2008; Chikagwa et al., 2009; Cherdthog et al., 2011). 
Aswandi

Based on data generated propionic acid, it was concluded that feed concentrates from grains and tubers contain digestible carbohydrates can increase the propionic acid composition, with respect to the banana weevil rock rich in carbohydrates (starch) can also generate sufficient propionic acid, which are reported as previous researchers mentioned above, so that it can be said that the varieties of banana weevil stones is also quite effective functioning of concentrate with other sources of feed ingredients in terms of producing propionic acid, which is expressed Huhtanen et al. (2007) feed that contains lots of fiber components (green) is more dominant will get the highest ratio of acetic acid was higher than propionate and butyrate, are more suitable for the purpose of producing milk (dairy cattle), whereas Shan et al. (2007) concentrate feed consisting of starch and legume leaves can increase the concentration of propionate and butyrate, acetate and propionate lower ratio and butyrate, to feed meat yield.

Based on the study of the correlation type of feed consumed on the composition of acetic acid and propionic acid produced, the composition $\mathrm{CF}_{0}$ treatment increased acetate, propionate and butyrate, while down, next on the composition of acetic acid $\mathrm{CF}_{3}$ treatment decreased, while propionate increased.

T-test results showed that treatment of $\mathrm{CF}_{0}$ and $\mathrm{CF}_{3}$ very different view significantly $(\mathrm{P}<0,01)$ of butyric acid composition of goat nut, with a difference of $16.57 \%$. The average composition of butyric acid $\mathrm{CF}_{0}, \mathrm{CF}_{3}$ : Successive $11.75 \mathrm{mM}, 16.42 \mathrm{mM}$, it appears that complete feed containing wheat banana weevil stones can enhance butyric acid composition as that produced butyric acid CF3 higher than the CF0, with respect to the composition of butyric acid produced from the study, researchers gave some of concentrate in animal experiments. Castellejos et al. (2007) produced $12 \mathrm{mM}$ butyric acid; Chikagwa et al. (2009) butyric acid from 10.3 to $11.1 \mathrm{mM}$; Cherdthong et al. (2011) butyric acid is concentrate feed forage $7.3 \mathrm{mM} 6.8 \mathrm{mM}$.

Based on the variable butyric acid is produced, it can be said that the banana weevil Stone can enhance butyric acid produced higher reported by previous investigators. The resulting differences in butyric acid caused $\mathrm{CF}_{0}$ and $\mathrm{CF}_{3}$ components of the feed composition, $\mathrm{CF}_{0}$ domination source of fiber (green) $70 \%$ king grass, with a crude fiber content of $28,71 \%, 67.23 \% \mathrm{NDF}$ and $\mathrm{ADF} 38.87 \%$, while the fiber $\mathrm{CF}_{3}$ roughly $23.75 \%, 55.03 \%$ $\mathrm{NDF}$ and ADF $48.72 \%$ more likely non structural carbohydrates of the soluble plant cells are sugars, mainly glucose, fructose and sucrose, polysaccharides, and starch.

T-test results showed that the treatment is different $\mathrm{CF}_{3}$ very real view of $\mathrm{CF}_{0}(\mathrm{P}<0.01)$ for total VFA, with the difference amounting to $8.78 \%$, higher than the $\mathrm{CF}_{3}$ ie, $106.19 \mathrm{mM} 89.04 \mathrm{mM}$, thus the banana weevil Stone can increase the concentration of volatile fatty acid (VFA) total goat nuts. This is due to the composition of the feed composition of $\mathrm{CF}_{0}$ source of fiber (green) $70 \%$ king grass, with a crude fiber content of $28,71 \%$, thus affecting the composition of the NDF and ADF $67.23 \% 38.87 \%$, while crude fiber CF3 lower at 23, 75\%, $55.03 \% \mathrm{NDF}$ and ADF $48.72 \%$, with respect to the line that expressed Donnem et al. (2011) VFA production affected source materials, physical properties and chemical components of feed material; Popova et al. (2011) states the total VFA production influenced the nature of carbohydrates, the rate of food leaving the rumen and feeding frequency.

The results of treatment of total VFA production CF0 CF3 $89.04 \mathrm{mM}$ and $106.19 \mathrm{mM}$; Castellejos et al. (2007) total VFA 94, $71 \mathrm{mM}$.. Based on total VFA variables resulting from the complete feed containing varieties of banana weevil rock pretty well and still in the optimum range for microbial activity in the rumen, which is expressed as Sutardi et al. (1983) a sufficient range of concentrations of VFA rumen microbial growth of 80-160 mM; Nkosi and Meeske (2010) is 70-130 $\mathrm{mM}$ in goat.

Blood Glucose. Test Results $-\mathrm{CF}_{3} \mathrm{t}$ shows that the treatment is very different from the real view of $\mathrm{CF}_{0}$ $(\mathrm{P}<0.01)$ on blood glucose, a difference of $8.33 \%$, the average blood glucose treatment $\mathrm{CF}_{0} 40 \mathrm{mg} / \mathrm{dl} ; \mathrm{CF}_{3} 52$ $\mathrm{mg} / \mathrm{dl}$. The resulting blood glucose higher than $\mathrm{CF}_{3}$ treatment $\mathrm{CF}_{0}$, indicating that the rock flour banana weevil can provide better energy than the $\mathrm{CF}_{0}$, as to which Harper et al. (1980) states that the source of blood glucose from carbohydrates between contained in the feed.

The findings of the blood glucose content in the two treatments was in the range of blood glucose levels are normal for goats, as stated by Frank et al. (2007) that a normal blood glucose levels in ruminant animals is lower than in non-ruminant animals 40-60 mg / dl; Lanzas et al. (2007) is $40 \mathrm{mg} / \mathrm{dl}$ in cows $60 \mathrm{mg} / \mathrm{dl}$. Based on the findings of the blood glucose content can be concluded that the blood glucose content was higher in cattle feed to get treatment $\mathrm{CF} 3$ carbohydrates can be digested and utilized better than $\mathrm{CF}$. 
T-test results showed that the treatment is different $\mathrm{CF} 3$ very real view of $\mathrm{CF}_{0}(\mathrm{t} \alpha 0.01)$ of complete feed consumption goat nuts, with a difference of $9.06 \%$, higher feed intake $\mathrm{CF}_{3}$ of the $\mathrm{CF}_{0}$. Average daily feed consumption in the treatment of $\mathrm{CF}_{0}$ and $\mathrm{CF}_{3}$ respectively 708.01 and $849.66 \mathrm{~g} / \mathrm{head} / \mathrm{day}$, amounting to 631.90 $\mathrm{g} /$ head/day or $(4.37 \%)$ of body weight and $751,95 \mathrm{~g} / \mathrm{head} /$ day or $(5.20 \%)$ of body weight, consumption of dry matter and $\mathrm{CF}_{3} \mathrm{CF}_{0}$ is higher than the dry matter requirement of guideline (Kearl, 1982).

Feed intake and dry matter CF3 in the study were higher than some previous researchers report (Salem et al., 2003; Simon et al., 2004; Rudiah, 2008; Simanihuruk, 2009; Suparjo et al., 2011).

The findings of complete feed intake and dry matter consumption of goat bean yield $\mathrm{CF}_{3}$ treatment consumption feed and dry matter intake is higher than the control, it is supported by the physical properties and composition of the banana weevil flour which reached $40 \%$ of total feed complete, will certainly affect the crude fiber content feed, making it possible to increase feed intake is complete, thus the major factor causing higher feed intake and dry matter in the $\mathrm{CF}_{3}$ associated with low fiber content and physical properties of banana flour weevil which contributed $40 \%$ of the total feed.

T-test results showed that the treatment is different $\mathrm{CF}_{3}$ very real view of $\mathrm{CF}_{0}(\mathrm{P}<0.01)$ on digestibility of dry matter, with a difference of $10.51 \%$, higher than the $\mathrm{CF}_{0}$ is 487.44 or $(72.90 \%)$ compared to $394,72 \mathrm{~g} / \mathrm{head} /$ day or $(68.59 \%)$ higher than the CF3 treatment CF0, whereas previous researchers reported: Hartadi et al. (1984) dry matter digestibility range goats of $393.1 \mathrm{~g} /$ head / day; Sanon et al. (2008) 387-492 g/head/day; Sauve et al. (2009) at 448-450 g/head/day.

Dry matter digestibility results obtained in the study, if confirmed by the results of previous research reports, that the dry matter digestibility of complete feed containing wheat banana weevil stone is higher than that obtained by previous researchers, this is possible because the fermentation process can be run better, NDF and ADF content of the manifestations that have better $\mathrm{CF}_{3}$, lower crude fiber with $\mathrm{CF} 0$, as expressed Tilaman et al. (1998) suggests a larger ration NDF 0\% will push the level of consumption and digestibility of dry matter. The structural components such as cellulose, lignin cell wall (NDF and ADF) negatively affect the nutrient digestibility of the ration, while the soluble carbohydrate (starch) can increase the digestibility of nutrients; Lanzas et al. (2007) stated that feed containing (starch) is high such as bulbs / seeds and non-structural carbohydrate concentrations classified (glucose, fructose, sucrose, and starch polysaccharides).

T-test results showed that the treatment is different $\mathrm{CF}_{3}$ very real view of $\mathrm{CF}_{0}(\mathrm{P}<0.01)$ to the energy consumption of kacang goat, with a difference of $31.41 \%$, the average energy consumption of $3.33 \mathrm{MJ} \mathrm{CF} /$ head / day or 0, $79 \mathrm{Mcal} /$ head / day while the CF3 of $6.38 \mathrm{MJ} /$ head / day (1.51 Mcal / head / day), if confirmed by energy needs, that the treatment under the standard drift CF0 energy needs, while the CF3 treatment in the range energy requirements based on the guidelines Kearl (1982), thereby CF3 that treatment will be able to meet the energy requirements for sheep nuts, because that allows CF3 has a higher energy content than the controls, supported by a complete feed digestibility of energy higher than that of $\mathrm{CF}_{3}$ is $\mathrm{CF}_{0} 77.57 \%$ sequentially and 58 , $28 \%$.

Consumption and digestibility of energy produced from goat nuts $\mathrm{CF}_{3}$ is higher than that reported Haque et al. (2008) range from 6.75 to $7.66 \mathrm{MJ}$ intake / head / day and digestibility from 5.84 to $6.10 \mathrm{MJ} / \mathrm{head} /$ day, whereas the digestibility of energy consumption and lower $\mathrm{CF}_{0}$. Consumption and energy digestibility can be said that the complete feed containing wheat banana weevil may play a role in stone to raise our energy consumption and digestibility of goat nuts, it is supported by one of the factors, including carbohydrate content contained in the complete feed at a higher $\mathrm{CF}_{3}$ treatment of the $\mathrm{CF}_{0}$.

Test results shows that the treatment is very different from the real view of $\mathrm{CF}_{0}(\mathrm{P}<0.01)$ on feed conversion completed goat nuts, $\mathrm{CF}_{3}$ treatment was higher than $\mathrm{CF}_{0}$ with a difference of $30.70 \%$. Average feed conversion of 15.54 while the complete $\mathrm{CF}_{0} 8.23 \mathrm{CF}_{3}$, of complete feed conversion generated very real $\mathrm{CF}_{3}$ lower, thus it can be stated that the $\mathrm{CF}_{3}$ more efficient in feed to produce body weight gain.

Complete conversion of the feed value of the findings can be interpreted that the $\mathrm{CF}_{0}$, to produce $1 \mathrm{~kg}$ of body weight needed goat nuts $15.54 \mathrm{~kg}$ dry matter, whereas the complete feed containing $\mathrm{CF}_{3}$ banana weevil varieties of stone, to produce $1 \mathrm{~kg}$ of body weight is only required 8 goat bean, $23 \mathrm{~kg}$ dry matter. Showed a complete feed 
containing wheat varieties banana weevil Stone over at converting feed to produce per unit body weight goat nuts, with respect to feed conversion value Tillman et al. (1998) defines the lower the value of the livestock feed conversion was more efficient in utilizing feed, while Prawoto et al. (2001) states that the conversion of feed and feed ingredients affected by ration formulation and nutrient content.

The findings feed conversion complete on research $\mathrm{CF}_{3}, \mathrm{CF}_{3}$ treatment that the conversion value under the range obtained by previous researchers, it is possible occurs because the banana weevil $\mathrm{CF}_{3}$-containing stones are rich in carbohydrates in the form of starch (starch) can be quickly digested and utilized by goats nuts and composition of $40 \%$ of the total feed, so the content of complete feed is also high in carbohydrates is equal to $71.39 \%$ and $67.10 \%$ of $\mathrm{CF}_{0}$, can have a significant impact on the rate of body weight gain of cattle goat nuts, will affect feed conversion, if the data in terms of body weight gain produced in $\mathrm{CF}_{3}$ is also higher than in controls.

Increase body weight. Test Results $-\mathrm{CF}_{3} \mathrm{t}$ shows that the treatment is very different from the real view of $\mathrm{CF}_{0}$ $(\mathrm{P}<0.01)$ daily body weight gain of kacang goat, with a difference of $35.48 \%$, with the average daily body weight gain of $49.58 \mathrm{~g} \mathrm{CF}_{0} / \mathrm{head} /$ days while the $\mathrm{CF}_{3}$ treatment of $104.11 \mathrm{~g} / \mathrm{head} / \mathrm{day}$, when several researchers confirmed previous reports of Simon et al. (2004) 54-64 g / head / day; Rantan et al. (2005) 60-97 g / head / day; Rudiah (2008) from 82.14 to $98.21 \mathrm{~g} /$ head / day; Simanihuruk (2009) from 80.86 to $106 \mathrm{~g} /$ head; and Suparjo et al. (2011) from 58.95 to $101 \mathrm{~g} / \mathrm{head} /$ day.

The resulting weight of the kacang goat $\mathrm{CF}_{3}$ treatment is higher than the $\mathrm{CF}_{0}$, indicating that the treatment of $\mathrm{CF}_{3}$-containing flour banana weevil Stones that are rich in carbohydrates can contribute better to the body weight gain kacang goat

Live body weight gain may be a reflection of the quality of feed given, the results obtained from the fact that a complete feeding starchy banana weevil-rich rocks that are easily digested carbohydrates can increase body weight gain goat nuts, when examined a manifestation of the level of material consumption goat dried beans from CF0 treatment of 631.90 and 751.95 of $\mathrm{CF}_{3} \mathrm{~g} /$ head /day, dry matter digestibility of treatment was significantly different $(\mathrm{P}<0.05) \mathrm{CF}_{0} 394.72 \mathrm{~g} / \mathrm{head} /$ day, $\mathrm{CF} 3487.44 \mathrm{~g} / \mathrm{head} /$ day, consumption of dry matter and dry matter digestibility is higher than the $\mathrm{CF}_{3}$ between $\mathrm{CF}_{0}$. Indicates that the nutrient intake and is absorbed by the beans of the CF3 goats will be greater than CF0, which is expressed as Setiadi (2003) feed is an important factor in supporting the growth of livestock, feed given must contain sufficient protein, carbohydrates, vitamins, minerals, non-toxic, like cattle, inexpensive and easy to digest

Carcass weights. T-test results showed that the treatment is different $\mathrm{CF}_{3}$ very real view of $\mathrm{CF}_{0}(\mathrm{t} \alpha 0.01)$ of the goat carcass weight of beans, with a difference of $15.93 \%$. Average carcass weight of $40 \mathrm{CF}_{0}, 43 \%$, while the $\mathrm{CF}_{3}$ at $45.25 \%$, the average carcass weight of sheep nuts $\mathrm{CF}_{3}$ treatment significantly higher than the $\mathrm{CF}_{0}$, due to the banana weevil $\mathrm{CF}_{3}$-containing rock rich in carbohydrate content in the form of starch (starch), with the composition of the rock component of the banana weevil flour by $40 \%$ of the total feed complete, and physical properties also support the fragile tuber flour, allowing the consumption and digestibility of dry matter is higher than the control diet, and other variables supported by energy consumption and energy digestibility also higher, there is increased development of tissue growth by increasing disposition on the part of carcass meat goat nuts higher than the $\mathrm{CF}_{0}$, thus certainly will affect the daily body weight gain and ultimately will result in parts of the carcass weight is higher as well.

Carcass weight of $\mathrm{CF} 3$ treatment is higher than some previous reports, thus it can be concluded that complete feed containing varieties of banana weevil can increase the weight of the stone nuts goat carcass, This suggests that the complete feed containing wheat banana weevil rock rich in carbohydrates can increase the growth rate of goats peanut better, which is expressed as Paramasivam et al. (2002) body composition is influenced by the rate of growth of cattle, cattle that grow faster will convert feed into body weight gain in the unit more efficient, thereby increasing the weight in carcass and subsequently affect the weight of the carcass.

Parts of carcass weight. T-test results showed that treatment of $\mathrm{CF}_{3}$ is very real and distinct $\mathrm{CF}_{0}(\mathrm{t} \alpha 0.01)$ on carcass weight parts of the neck (neck), shoulder (neck), Brest (chest); leg chump on (thigh); ribs; loin, fore shank and flank. Average carcass weight of the parts resulting from the treatment of $\mathrm{CF}_{3}$ is higher than the $\mathrm{CF}_{0}$ shown. Showed that the complete feed containing wheat banana weevil rocks, rich in carbohydrates to give a positive response to the growing weight of the parts carcass, the results of this study are expressed in line Legesse et al. (2006) found the quality of food, sex affects the growth lemusir loin, ribs, back ribs, neck and neck; then Titi et al. (2007) states the component parts of carcasses of sheep and goats in the part: leg, loin, neck, 
and shoulder, were significantly different at the level of 5\%, and Hailu et al. (2005) that the weight of shoulder and neck goats are higher than in females, whereas the weight of other parts of the carcass did not give a significant influence. Alexandear et al. (2010) also reported that feeding forage (fiber), compared with the provision of commercial concentrates, an increase in weight of the leg, shoulder and the ribs better

Differences in the carcass weight produced markedly higher than the $\mathrm{CF}_{3}$ between $\mathrm{CF}_{0}$, this difference is a result of the network composed of meat carcass parts that influenced the rate of growth, which is expressed as Looper et al. (2005) states that the weight of carcass components affected the nation, gender, genetics, growth rate, weight cutting and treatment of feed; Rianto et al. (2006) states that the composition of the body parts of animals affected by the rate of growth, then Hailu et al. (2005) also suggested that factors affecting growth, carcass and its parts including the genetic, environmental, maintenance management, most determine the genetic and feed sufficient quantity and quality, for which the results obtained in this study that the treatment of contentrich $\mathrm{CF}_{3}$ soluble carbohydrate (digested) by the goat bean, which is supported by the digestibility of dry matter produced is also higher at $487.44 \mathrm{~g} /$ head/day, whereas the $\mathrm{CF}_{0} 394.72 \mathrm{~g} / \mathrm{head} /$ day.

\section{CONCLUSION}

$\mathrm{CF}_{3}$ treatment produces $\mathrm{pH}, \mathrm{NH}_{3}$, propionic acid, Butyrate, blood glucose and total VFA best goat nuts compared to the control treatment. Complete feed containing wheat banana weevil pea stone sheep productivity is better than complete control of feed.

\section{REFERENCES}

1. Alexandre G, Limea L, Nepos A, Fleury A, Lallo C and Archimede H (2010). The offal components and carcass measurements of Creole kids of Guadeloupe under various feeding regimes. Livestock Research for Rural Development 22: 100 .

2. Castellejos L, Calsamiglia S, Martin J, Tereso H and Wijlen T (2008). In vitro evaluation of effects of ten essential oils at three doses on ruminal fermentation of high concentrate feedlot-type diets. Animal Feed Science and Technology 145: 259-270.

3. Cherdthong A, Wanapat M and Wachirapakorn C (2011). Influence of urea calcium mixture supplementation on ruminal fermentation characteristics of beef cattle fed on concentrates containing high levels of cassava chips and rice straw. Animal Feed Science and Technology 163: 43-51.

4. Chikagwa MSK, Adesogan AT, Szabo NJ, Littell RC, Phatak SC, Kim SC, Arriola KG, Huisden CM, Dean DB, Krueger NA (2009). Nutritional characterization of Mucuna pruriens. 3. Effect of replacing soybean meal with Mucunaon intake, digestibility, N balance and microbial protein synthesis in sheep. Animal Feed Science and Technology 148:107-123.

5. Donnem IA, Randby T and Eknaes M (2011). Effects of grass silage harvesting time and level of concentrate supplementation on nutrient digestibility and dairy goat performance. Animal Feed Science and Technology 163: $150-160$

6. Forrest JC, Aberle EB, Hedrick HB, Judge MD and Merkel RA (1975). Principles of Meat Science. W.H. Feeman and Co., San Francisco.

7. France J and Seddons RC (1993). Volatile fatty acid production In Forbes. J.M and J. Fronce. Ed Quantitative aspects of ruminant digestion and metabolism. C. A. B. International. Walingterd. 107-121.

8. Frank RS and Nancy EW (2007). Environmental management of concentrated animal feeding operations (CAFOs), Taylor \& Francis Group, Boca Raton, London, New York, CRC Press. 8493-7098.

9. Gerona GR, Sanchez SL, Posas OB, Anduyan GAP, Jaya AF and Barrientos CG (1987). Utilization of banana plant residue by ruminants. In: Dixon RM ed. Ruminants Feeding System Utilizing Fibrous Agricultural Residues. Canberra.147-151.

10. Goering HK and Van Soest PJ (1970). Forage Fiber Analysis. Agricultural Handbook No.379. United States Department of Agriculture. Washington DC. 12-15.

11. Harper HA, Rodwell VW and Mayes PA (1980). Biokimia (Review Physiological Chmistry). Edisi ke- 17. Penerbit Buku Kedokteran E. G. C. Jakarta. (Diterjemahkan oleh M. Muliawan).

12. Hailu D, Tatek W and Tesfaye L (2005). Comparison of carcass characteristics of Boran and Arsi-Bale goats under different durations of feedlot management. Livestock Research for Rural Development 17: 7.

13. Haque N, Toppo S, Saraswat ML and Khan MY (2008). Effect of feeding Leucaena leucocephala leaves and twigs on energy utilization by goats. Animal Feed Science and Technology 142: 330-338. 
14. Hartadi H, Reksohadiprodjo S and dan Tilman AD (1997). Tabel Komposisi Pakan untuk Indonesia. Cetakan ke5. Gadjah Mada Press, Yogyakarta.

15. Huhtanen P, Rinne M and Nousiainen J (2007). Evaluation of the factors affecting silage intake of dairy cows: a revision of the relative silage dry-matter intake index. Animal 1: 758-770.

16. Kearl LC (1982). Nutrient requirements of ruminants in developing countries. International Feedstuffs Institute. Utah Agricultural Experiment Station Utah State University Logan. Utah.

17. Lanzas C, Sniffen CJ, Seo S, Tedeschi LO and Fox DG (2007). A revised CNCPS feed carbohydrate fractionation scheme for formulating rations for ruminants. Animal Feed Science and Technology 136: 167-190.

18. Legesse G and Abebe G (2008). The effect of breed type and feeding system on yields of edible and saleable components of Somali and Arsi- Bale goats. Livestock Research for Rural Development 20.

19. Looper M L, Burke JM, Mcbeth LJ, Krehbiel CR, Flores R, Rosenkrans Jr. CF and Alken GE (2005). Effects of time constriction on growth, feedlot performance, and carcass characteristics of Angus and Charolais-sired calves. American Society of Animal Science Southern Section Meeting Journal of Animal Science 83: 32.

20. McCormick ME, Redfearn DD, Ward JD and Blouin DC (2001). Effect of protein source and soluble carbohydrate addition on rumen fermentation and lactation performance of Holstein cows. Journal of Dairy Science 84:16861697.

21. Muhtarudin dan Leman (2006). Penentuan tingkat penggunaan mineral organik untuk memperbaiki bioproses rumen pada kambing secara in vitro. Jurnal Ilmu-Ilmu Pertanian Indonesia 8: 132-140.

22. Owens D, McGee M, Boland T and O'Kiely P (2008). Intake, rumen fermentation and nutrient flow to the omasum in beef cattle fed grass silage fortified with sucrose and/or supplemented with concentrate. Animal Feed Science and Technology 144: 23-43.

23. Paramasivam A, Arunachalam S, Sivakumar T and Ramesh V (2002). Growth performance and carcass traits of Barbari goats under different systems of management. Indian Journal of Animal Sciences 72: 1016-1018

24. Popova M, Martin C, Eugène M, Mialon MM, Doreau M and Morgavi DP (2011). Effect of fibre- and starch-rich finishing diets on methanogenic Archaea diversity and activity in the rumen of feedlot bulls. Animal Feed Science and Technology 167: 113-121.

25. Prawoto JA, Lestari CMS and Purbowati dan E (2001). Keragaan dan kinerja produksi domba lokal yang dipelihara secara intensif dengan memanfaatkan ampas tahu sebagai bahan pakan campuran. Jurnal Pengembangan Peternakan Tropis 277-285.

26. Rantan, K., Simon dan P Genting. (2005). Produktivitas Kambing Kacang Dengan Pemberian Pakan Komplit Kulit Buah Markisah Terfermentasi Aspergillus Niger. Prosiding Seminar Nasional Teknologi Peternakan dan Vatriner. 625-629

27. Rianto E, Lindasari E and Purbowati dan E (2006). Pertumbuhan dan Komponen Fisik Karkas Domba Ekor Tipis Jantan yang Mendapat Dedak Padi dengan Aras Berbeda. Journal of Animal Production 8: 28-33.

28. Rudiah (2008). Pengaruh Waktu Pemberian Pakan Terhadap Perporma Kambing Kacang Jantan. Journal of Agrisain 9:50-56

29. Salem HB, Salem IB, Nefzaoui A and Said MSB (2003). Effect of PEG and olive cake feed blocks supply on feed intake, digestion, and health of goats given kermes oak (Quercus coccifera L.) foliage. Animal Feed Science and Technology 110: 45-59.

30. Santosa, Budi P and Ashari dan (2005). Analisis statistik dengan Microsoft Excel dan SPSS. Ed. I. Penerbit Andi Yogyakarta.

31. Sanon HO, Kabore- Zoungrana C and Ledin I (2008). Nutritive value and voluntary feed intake by goats of three browse fodder species in the Sahelian zone of West Africa. Animal Feed Science and Technology 144: 97-110.

32. Sauve AK, Huntington GB and Burns JC (2009). Effects of total nonstructural carbohydrates and nitrogen balance on voluntary intake of goats and digestibility of gamagrass hay harvested at sunrise and sunset. Animal Feed Science and Technology 148: 93-106.

33. Setiadi B (2003). Alternatif konsep pembibitan dan. Pengembangan usaha ternak kambing. Makalah pada sarasehan potensi ternak kambing dan proyek agribisnis peternakan. Bungkulu.

34. Shan JG, Tan ZL, Sun ZH, Hu JP, Tang SX, Jiang HL, Zhou CS, Wang M and Tayo GO (2007). Limiting amino acids for growing goats fed a corn grain, soybean meal and maize stover based diet. Animal Feed Science and Technology 139: 159-169.

35. Simanihuruk K (2009). Utilization of passion fruit bulls (passiflora edulis sims edulis Deg) as component of complete feed for growing kacang goats. 14: 36-34. 


\section{Aswandi}

36. Simon P,Ginting, Batubara LP, Tarigan A and Kresno dan Junjungan R (2004). Pemanfaatan limbah industri pengolahan sayur lobak (Rapharus sativus) sebagai pakan kambing. Abstrak. Seminar Nasional Teknologi Peternakan dan Vateriner.

37. Sunarso, Haryanto B, Kurnianto E, Kuswandi, Setiadi A, Nuswantara LK and Christiyanto M (2007). Inroduksi Teknologi Complete Feed dalam Upaya Peningkatan Produksi dan Prduktivitas Sapi Potong. Badan Penelitian dan Pengembangan Pertanian. Departemen Pertanian. Jakarta.

38. Suparjo K, Wiryuwan G, Laconi EB and Mangun Widjaja D (2011). Performa Kambing yang Diberi Kulit Buah Kakao Terfermentasi. Media Peternakan 35-41.

39. Sutardi T (1977). Iktisar Ruminologi. Bahan Kursus Peternakan Sapi perah Kayu Ambon. Dirjen PeternakanFAO.

40. Sutardi T, Sigit NA and Toharmant T (1983). Standarisasi Mutu Protein Bahan Makanan Ruminansia Berdasarkam Parameter Metabolisme oleh Mikroba Rumen. Proyek Pengembangan Ilmu dan Teknologi. Departemen Pendidikan dan Kebudayaan. Direktorat Jendral Pendidikan Tinggi. Jakarta Pusat. Departemen Pertanian Jakarta.

41. Tillman AD, Hartadi H, Reksohadiprojo S, Prawirokusumo S and Lebdosoekojo S (1998). Makanan Ternak Dasar. Cetakan ke 4. Gadjah Mada University Press, Yogyakarta.

42. Titi HH, Dmour RO and Abdullah AY (2007). Growth performance and carcass characteristics of Awassi lambs and Shami goat kids feed yeast culture in their finishing diet. Animal Feed Science and Technology 142: 33-43.

43. Willamson G and Payne WJA (1993). Introduction to Animal Husbandry in the tropics. Gadjah Mada University Press, Yogyakarta. Translated by S.G.N.D. Darmadja. 